\title{
Workers exposed to ethylene oxide: a follow up study
}

\author{
M J GARDNER, D COGGON, B PANNETT, E C HARRIS \\ From the MRC Environmental Epidemiology Unit (University of Southampton), Southampton General \\ Hospital, Southampton SO9 $4 X Y, U K$
}

ABSTRACT A cohort study has been carried out of 2876 men and women with potential exposure to $\vec{\circ}$ ethylene oxide. Subjects were identified from employment records at four companies that have $\overrightarrow{\vec{\omega}}$ produced or used ethylene oxide since the 1950s and at eight hospitals which have had ethylene oxide $\stackrel{\omega}{\circ}$ sterilising units since the 1960s. The cohort represents a substantial proportion of the British $\bigodot_{\Phi}$ workforce with a history of occupational exposure to ethylene oxide. Industrial hygiene data were not $?$ available before 1977, but since then time weighted average exposures have been less than 5 ppm in $\overrightarrow{+}$ almost all jobs and less than $1 \mathrm{ppm}$ in many. Past exposures were probably somewhat higher. In $\overrightarrow{\mathrm{N}}$ contrast to some previous studies, no clear excess of leukaemia (three deaths observed, 2.09 expected) ${ }_{\circ}^{\circ}$ and no increase in stomach cancer (five deaths observed, 5.95 expected) were found. This discrepancy with earlier reports may be due in part to differences in levels of exposure. Total cancer mortality was 5 similar to that expected from national and local death rates. Some specific cancers showed small $\vec{\square}$ excesses but their relevance to ethylene oxide exposure is doubtful. Again, contrary to some earlier ${ }_{\varnothing}^{\circ}$ reports, no excess of cardiovascular disease was found. This study does not exclude the possibility $\frac{\Phi}{3}$ that ethylene oxide is a human carcinogen but suggests that any risk of cancer from currently ${ }_{\mathbb{\Phi}}$ permitted occupational exposures is small.

Ethylene oxide is a powerful mutagen and a proved cause of cancer in laboratory animals, ${ }^{12}$ but its potential to cause cancer in man is still uncertain. ${ }^{3}$ Epidemiological studies have linked the compound with the occurrence of leukaemia and stomach cancer $^{4-6}$ but these associations are based on relatively small numbers of cases, and interpretation is complicated by the possibility of confounding exposure to other chemicals such as benzene.

The main uses of ethylene oxide are as a chemical intermediate in the manufacture of ethylene glycol and non-ionic detergents, as a sterilant gas for the treatment of medical equipment and cosmetics, and as a fumigant of cocoa beans and spices. In view of these wide ranging applications, it is important to establish the extent of any risk to exposed workers. Moreover, study of compounds such as ethylene oxide may enhance understanding of the relation between mugagenicity and human carcinogenicity and thereby allow more accurate prediction of those chemicals likely to prove hazardous to man.

We have therefore carried out a cohort study of mortality among 2876 men and women exposed to ethylene oxide during its manufacture and use in England and Wales.

Accepted 30 January 1989

\section{Method}

\section{STUDY COHORT}

The study cohort comprised employees from three. companies that produced ethylene oxide and derivative compounds such as polyethylene glycols and ethoxylates, from one company that manufac $-\overrightarrow{0}$ tured alkoxides from ethylene oxide that had been 3 bought in, and from eight hospitals with ethylene oxide sterilising units. There were no representatives:from the pharmaceutical or food industries because inquiries had indicated that the number of exposed 3 workers at individual companies was too small too warrant inclusion. For similar reasons, employees at hospitals with only small ethylene oxide sterilisers (lesso than 100 litres) were also excluded.

Tables 1 and 2 give further details of the participat-O ing companies and hospitals and of the criteria for $>$ entry to the cohort. All the chemical companies had을. handled ethylene oxide from 1960 or earlier, whereas the compound was not used at any of the hospitalso before 1962. By the mid-1980s exposure at three of the $\tilde{}$ hospitals had effectively ceased, either because ethylene oxide was no longer used or because the sterilisingo procedure had been enclosed. Subjects were identified from written personnel records except at companies $A_{\bar{\Phi}}^{\complement}$ and $\mathrm{B}$ where computerised personnel data were used.? 
Table 1 Companies participating in the study

\begin{tabular}{|c|c|c|c|}
\hline \multicolumn{2}{|c|}{ Company Chemicals produced at site } & \multirow{2}{*}{$\begin{array}{l}\text { Definition of cohort } \\
\text { All employees assigned to ethylene } \\
\text { oxide plants } 1.1 .1956-31.12 .1978 \\
\text { (maintenance workers were not } \\
\text { assigned to specific plants or areas } \\
\text { and were excluded) }\end{array}$} & \multirow{2}{*}{$\begin{array}{l}\text { Possible exposures other than ethylene } \\
\text { oxide } \\
\text { Chlorhydrin, ethylene oxide derivatives, } \\
\text { propylene oxide, benzene, styrene, } \\
\text { asbestos, and others }\end{array}$} \\
\hline $\mathbf{A}$ & $\begin{array}{l}\text { Ethylene oxide: } \\
\text { Chlorhydrin process } 1950-60 \\
\text { Direct oxidation 1959- } \\
\text { Ethylene oxide derivatives } 1959- \\
\text { Propylene oxide and derivatives } \\
\text { Many other petrochemicals }\end{array}$ & & \\
\hline B & $\begin{array}{l}\text { Ethylene oxide: } \\
\text { Chlorhydrin process 1955-70 } \\
\text { Direct oxidation 1970- } \\
\text { Ethylene oxide derivatives 1955- } \\
\text { Propylene oxide and derivatives } \\
\text { Many other petrochemicals }\end{array}$ & $\begin{array}{l}\text { All employees assigned to ethylene } \\
\text { oxide plants } 1.7 .1976-30.4 .1985 \\
\text { (maintenance workers were assigned } \\
\text { to specific plants and were included) }\end{array}$ & $\begin{array}{l}\text { Chlorhydrin, ethylene oxide derivatives, } \\
\text { propylene oxide, aliphatic and } \\
\text { aromatic hydrocarbons including } \\
\text { benzene, butadiene, heavy fuel oils } \\
\text { and tars, asbestos, and others }\end{array}$ \\
\hline $\mathbf{C}$ & $\begin{array}{l}\text { Ethylene oxide: } \\
\quad \text { Direct oxidation } 1960-81 \\
\text { Ethylene oxide derivatives } 1960- \\
\text { Propylene oxide derivatives } \\
\text { Acrylates }\end{array}$ & $\begin{array}{l}\text { All permanent male employees with } \\
\text { potential exposure to ethylene oxide } \\
1.5 .1960-30.6 .1985\end{array}$ & $\begin{array}{l}\text { Ethylene oxide derivatives, propylene } \\
\text { oxide, benzene, white spirit, asbestos, } \\
\text { and others }\end{array}$ \\
\hline D & $\begin{array}{l}\text { Ethylene oxide derivatives } 1959- \\
\text { Propylene oxide derivatives } \\
\text { Sulphates } \\
\text { Phthalates } \\
\text { Esters }\end{array}$ & $\begin{array}{l}\text { All employees assigned to ethylene } \\
\text { oxide plants and all maintenance } \\
\text { engineers } 1.1 .1963-31.10 .1985\end{array}$ & $\begin{array}{l}\text { Ethylene oxide derivatives, propylene } \\
\text { oxide, methanol, benzene, methylene } \\
\text { chloride, formaldehyde, } \\
\text { dimethylamine, cadmium oxide, } \\
\text { asbestos, and others }\end{array}$ \\
\hline
\end{tabular}

We attempted to include all employees with likely exposure to ethylene oxide at any time before data abstraction but because employment records were incomplete for some early periods it was not always possible to ascertain exposed workers for the entire duration of ethylene oxide manufacture or use. For each subject we obtained basic identification details together with dates of starting and leaving employment and descriptions of all jobs undertaken.

\section{JOBS AND EXPOSURE CLASSIFICATION}

With help from management at the companies and hospitals, and before carrying out any analysis of mortality, we classified jobs according to their potential for exposure to ethylene oxide. At the chemical factories we distinguished jobs that entailed definite exposure (workers assigned specifically to ethylene

Table 2 Hospitals participating in the study

\begin{tabular}{lll}
\hline Hospital & $\begin{array}{l}\text { Dates of ethylene } \\
\text { oxide use }\end{array}$ & $\begin{array}{l}\text { Period for which } \\
\text { cohort was ascertained }\end{array}$ \\
\hline E & $1962-$ & $01.06 .1964-10.12 .1984$ \\
F & $1972-1984$ & $01.07 .1972-30.06 .1984$ \\
$\mathbf{G}^{*}$ & $1965-1984$ & $01.07 .1975-31.12 .1984$ \\
H $_{\text {I }}^{1969-}$ & $01.07 .1969-31.08 .1985$ \\
J & $1971-$ & $01.07 .1971-30.09 .1985$ \\
K* & $1971-$ & $01.09 .1974-30.09 .1985$ \\
L & $1968-1982$ & $01.09 .1968-31.07 .1980$ \\
& $1965-$ & $01.07 .1965-30.09 .1986$ \\
\hline
\end{tabular}

*Use continued after the period shown but improvements in engineering meant that exposure was effectively eliminated.

tAt each hospital the cohort comprised all sterilising unit employees with potential exposure to ethylene oxide during the stated periods. oxide plants), jobs with probable exposure (mainly maintenance engineers who worked on several plants including the ethylene oxide area), and jobs that were poorly described but which possibly involved contact with ethylene oxide. Jobs at the hospitals were classed as entailing continual exposure (people who worked continuously in the sterilising room), intermittent exposure (porters and others who spent only part of their working day in the sterilising room), and possible exposure (poorly described jobs). In the early part of the study period exposure in the hospitals occurred not only during the loading and unloading of sterilisers but also through desorption of gas from articles stored in the work area after sterilisation.

Industrial hygiene data were not available for any of the facilities before 1977, but environmental and personal monitoring carried out since then indicated time weighted average exposures of less than $5 \mathrm{ppm}$ in almost all jobs. Occasional peaks of exposure up to several hundred ppm occurred as a result of operating difficulties in the chemical plants and during loading and unloading of sterilisers in the hospitals. In earlier years average exposures were probably-somewhat higher and peak exposures above the odour threshold of $700 \mathrm{ppm}$ were reported by manufacturers and at the hospitals.

Apart from ethylene oxide, some hospital workers experienced occasional low exposure to formaldehyde and carbon tetrachloride but there was little potential for confounding by occupational activities. By contrast, the chemical workers were exposed to a wide range of compounds including chlorhydrin, propylene 
Table 3 Numbers of individuals in the study cohort by place of employment, sex, and exposure status

\begin{tabular}{|c|c|c|c|c|c|c|}
\hline \multirow[t]{2}{*}{$\begin{array}{l}\text { Place of } \\
\text { employment }\end{array}$} & \multirow[t]{2}{*}{ Men } & \multirow[t]{2}{*}{ Women } & \multicolumn{3}{|c|}{ Exposure status* } & \multirow[t]{2}{*}{ Tota } \\
\hline & & & Definite & Possible & Unknown & \\
\hline $\begin{array}{c}\text { Company: } \\
\text { A } \\
\text { B } \\
\text { C } \\
\text { D }\end{array}$ & $\begin{array}{l}402 \\
306 \\
447 \\
315\end{array}$ & $\begin{array}{l}0 \\
1 \\
0 \\
0\end{array}$ & $\begin{array}{r}402 \\
303 \\
28 \\
154\end{array}$ & $\begin{array}{r}0 \\
0 \\
205 \\
151\end{array}$ & $\begin{array}{r}0 \\
4 \\
214 \\
10\end{array}$ & $\begin{array}{l}402 \\
307 \\
447 \\
315\end{array}$ \\
\hline Total & 1470 & 1 & 887 & 356 & 228 & 1471 \\
\hline $\begin{array}{c}\text { Hospital: } \\
\text { E } \\
\text { F } \\
\text { G } \\
\text { H } \\
\text { I } \\
\text { J } \\
\text { K } \\
\text { L }\end{array}$ & $\begin{array}{r}202 \\
10 \\
20 \\
26 \\
36 \\
25 \\
41 \\
34\end{array}$ & $\begin{array}{r}339 \\
112 \\
51 \\
72 \\
95 \\
73 \\
124 \\
145\end{array}$ & $\begin{array}{l}\text { Continual } \\
49 \\
115 \\
69 \\
94 \\
108 \\
11 \\
102 \\
166\end{array}$ & $\begin{array}{c}\text { Intermittent } \\
11 \\
7 \\
2 \\
4 \\
22 \\
87 \\
3 \\
13\end{array}$ & $\begin{array}{c}\text { Unknown } \\
481 \\
0 \\
0 \\
0 \\
1 \\
0 \\
60 \\
0\end{array}$ & $\begin{array}{r}541 \\
122 \\
71 \\
98 \\
131 \\
98 \\
165 \\
179\end{array}$ \\
\hline Total & 394 & 1011 & 714 & 149 & 542 & 1405 \\
\hline Total & 1864 & 1012 & & & & 2876 \\
\hline
\end{tabular}

*Each subject was classed to the highest exposure category in which he or she worked.

oxide, styrene, and benzene. Because there was particular concern about the risk of leukaemia, jobs were also coded for their potential exposure to benzene. Table 1 gives further details of possible confounding exposures. (More information on exposure patterns is available from the authors on request.)

\section{FOLLOW UP}

The study cohort was traced through the National Health Service Central Register (NHSCR) for England and Wales which provided us with information on current vital status and copies of death certificates where appropriate. If an individual's record could not be located at NHSCR we attempted

Table 4 Mortality by major cause of death and place of employment

\begin{tabular}{|c|c|c|c|c|}
\hline \multirow{2}{*}{$\begin{array}{l}\text { Cause of death } \\
\text { study cohort } \\
\text { subgroup }\end{array}$} & \multicolumn{2}{|c|}{ No of deaths } & \multirow[b]{2}{*}{$O / E$} & \multirow{2}{*}{$\begin{array}{l}95 \% \\
C I \text { for } O / E\end{array}$} \\
\hline & Obs & $\operatorname{Exp}$ & & \\
\hline \multicolumn{5}{|c|}{ Malignant neoplasms: } \\
\hline $\begin{array}{l}\text { Companies } \\
\text { Hospitals }\end{array}$ & $\begin{array}{l}53 \\
32\end{array}$ & $\begin{array}{l}46.60 \\
30.04\end{array}$ & $\begin{array}{l}1 \cdot 14 \\
1.07\end{array}$ & $\begin{array}{l}0.85-1.49 \\
0.73-1.50\end{array}$ \\
\hline \multicolumn{5}{|c|}{ Ischaemic heart disease: } \\
\hline $\begin{array}{l}\text { Companies } \\
\text { Hospitals }\end{array}$ & $\begin{array}{l}53 \\
15\end{array}$ & $\begin{array}{l}58 \cdot 60 \\
20 \cdot 15\end{array}$ & $\begin{array}{l}0.90 \\
0.74\end{array}$ & $\begin{array}{l}0.68-1.18 \\
0.42-1.23\end{array}$ \\
\hline \multicolumn{5}{|c|}{ Cerebrovascular disease: } \\
\hline $\begin{array}{l}\text { Companies } \\
\text { Hospitals }\end{array}$ & $\begin{array}{r}12 \\
5\end{array}$ & $\begin{array}{r}11 \cdot 82 \\
7.97\end{array}$ & $\begin{array}{l}1.02 \\
0.63\end{array}$ & $\begin{array}{l}0.53-1.77 \\
0.20-1.46\end{array}$ \\
\hline \multicolumn{5}{|l|}{ All other causes: } \\
\hline $\begin{array}{l}\text { Companies } \\
\text { Hospitals }\end{array}$ & $\begin{array}{l}39 \\
17\end{array}$ & $\begin{array}{l}54 \cdot 96 \\
28 \cdot 70\end{array}$ & $\begin{array}{l}0.71 \\
0.59\end{array}$ & $\begin{array}{l}0.50-0.97 \\
0.35-0.95\end{array}$ \\
\hline \multicolumn{5}{|l|}{ All causes: } \\
\hline $\begin{array}{l}\text { Companies } \\
\text { Hospitals }\end{array}$ & $\begin{array}{r}157 \\
69\end{array}$ & $\begin{array}{r}171.98 \\
86.86\end{array}$ & $\begin{array}{l}0.91 \\
0.79\end{array}$ & $\begin{array}{l}0.78-1.07 \\
0.62-1.01\end{array}$ \\
\hline
\end{tabular}

to trace it through Department of Health and Social $\vec{\nabla}$ Security (DHSS) records. Any additional information that came to light in this way was forwarded to 3 NHSCR for a further search. Underlying causes of death were coded to the ninth revision of the International Classification of Diseases. ${ }^{7}$ NHSCR a\&o 0 provided us with details of any cancers that had been.e registered in living cohort members.

The mortality analysis reported here is from the data of entry to the cohort (the data from which employment records were complete or the date when the individual was first potentially exposed to ethylene oxide, whichever came later) to 31 December 1987.2 The numbers of observed deaths have been compared with those expected on the basis of the cause, sex, and age specific death rates for appropriate five year calendar periods in England and Wales. The expected numbers were calculated by the person-years method, using a computer program (PYCL) adapted from that 3 of Hill. ${ }^{8}$ Confidence intervals for ratios of observed to expected deaths were calculated by the usual methods based on the Poisson distribution.

\section{Results}

Altogether, 2892 subjects satisfied the criteria for entry to the study but 16 had to be excluded from the $\%$ analysis because one or more of their sex, date of birth, $N$ or date of first potential exposure to ethylene oxide $N$ was unknown. Of the remaining 2876 subjects, 1864 were men and 1012 were women.
wer

Table 3 shows the distribution of the cohort by place of employment, sex, and level of exposure to ethylene 
Table 5 Mortality from leukaemia by place of employment and exposure status

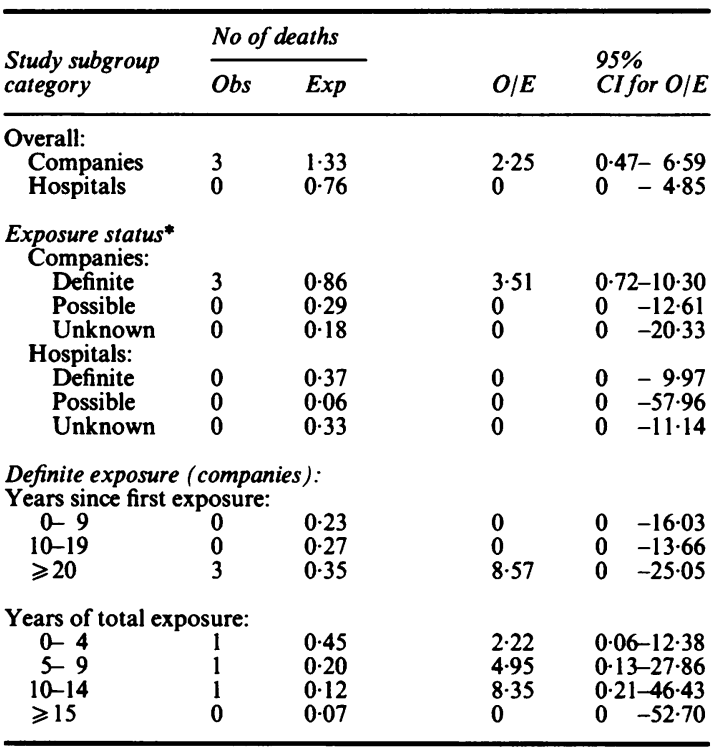

*Each subject was classed to the highest exposure category in which he or she worked.

oxide. About half the subjects came from companies and half from hospitals. All but one of the chemical workers were men, whereas more than two thirds of the hospital employees were women. Because some job titles were non-specific, many of the subjects at company $C$ and hospitals $E$ and $K$ were classed to the "unknown" exposure category. Most of these men and women would have been exposed to ethylene oxide but it was not possible to assign levels of exposure on an individual basis.

Table 6 Mortality from stomach cancer by place of employment and exposure status

\begin{tabular}{|c|c|c|c|c|}
\hline \multirow{2}{*}{$\begin{array}{l}\text { Study subgroup } \\
\text { category }\end{array}$} & \multicolumn{2}{|c|}{ No of deaths } & \multirow[b]{2}{*}{$O / E$} & \multirow{2}{*}{$\begin{array}{l}95 \% \\
C I \text { for } O / E\end{array}$} \\
\hline & Obs & $\operatorname{Exp}$ & & \\
\hline $\begin{array}{l}\text { Overall: } \\
\text { Companies } \\
\text { Hospitals }\end{array}$ & $\begin{array}{l}3 \\
2\end{array}$ & $\begin{array}{l}4 \cdot 28 \\
1.67\end{array}$ & $\begin{array}{l}0 \cdot 70 \\
1 \cdot 19\end{array}$ & $\begin{array}{l}0.15-2.05 \\
0.15-4.32\end{array}$ \\
\hline \multicolumn{5}{|l|}{$\begin{array}{c}\text { Exposure status* } \\
\text { Companies: }\end{array}$} \\
\hline $\begin{array}{l}\text { Definite } \\
\text { Possible } \\
\text { Unknown } \\
\text { Hospitals: }\end{array}$ & $\begin{array}{l}3 \\
0 \\
0\end{array}$ & $\begin{array}{l}2.92 \\
0.86 \\
0.50\end{array}$ & $\begin{array}{l}1 \cdot 03 \\
0 \\
0\end{array}$ & $\begin{array}{l}0.21-3.01 \\
0-4.29 \\
0-7.38\end{array}$ \\
\hline $\begin{array}{l}\text { Definite } \\
\text { Possible } \\
\text { Unknown }\end{array}$ & $\begin{array}{l}2 \\
0 \\
0\end{array}$ & $\begin{array}{l}0.86 \\
0 \cdot 16 \\
0.65\end{array}$ & $\begin{array}{l}2 \cdot 32 \\
0 \\
0\end{array}$ & $\begin{array}{lr}0.28-8.40 \\
0 & -23.06 \\
0 & -5.68\end{array}$ \\
\hline
\end{tabular}

*Each subject was classed to the highest exposure category in which he or she worked.
Table 7 Mortality from specific cancer by place of employment

\begin{tabular}{|c|c|c|c|c|}
\hline \multirow[b]{3}{*}{ Cancer } & \multirow{2}{*}{\multicolumn{2}{|c|}{$\frac{\text { Companies }}{\text { No of deaths }}$}} & \multirow{2}{*}{\multicolumn{2}{|c|}{$\frac{\text { Hospitals }}{\text { No of deaths }}$}} \\
\hline & & & & \\
\hline & Obs & $\operatorname{Exp}$ & Obs & $\operatorname{Exp}$ \\
\hline $\begin{array}{l}\text { Oesophagus } \\
\text { Stomach } \\
\text { Large intestine } \\
\text { Pancreas } \\
\text { Lung } \\
\text { Breast } \\
\text { Prostate } \\
\text { Bladder } \\
\text { Non-Hodgkin's lymphoma } \\
\text { Leukaemia } \\
\text { Other cancers }\end{array}$ & $\begin{array}{r}3 \\
3 \\
2 \\
3 \\
22 \\
0 \\
1 \\
3 \\
2 \\
3 \\
11\end{array}$ & $\begin{array}{r}1.52 \\
4.28 \\
2.85 \\
2.05 \\
18.44 \\
0.06 \\
1.65 \\
1.49 \\
1.04 \\
1.33 \\
11.89\end{array}$ & $\begin{array}{l}2 \\
2 \\
3 \\
1 \\
7 \\
4 \\
2 \\
1 \\
2 \\
0 \\
8\end{array}$ & $\begin{array}{r}0.68 \\
1.67 \\
2.12 \\
1.14 \\
6.11 \\
5.91 \\
0.26 \\
0.54 \\
0.57 \\
0.76 \\
10.28\end{array}$ \\
\hline All cancers & 53 & $46 \cdot 60$ & 32 & 30.04 \\
\hline
\end{tabular}

By 31 December 1987, $226(8 \%)$ members of the cohort had died. Thirty eight $(1 \cdot 3 \%)$ subjects could not be traced at NHSCR or DHSS (mainly due to inadequate identification in the basic records that we had used for abstraction, in particular the availability of only initials rather than full forenames) and could only be followed up to their date of last employment. A further $95(3.3 \%)$ had emigrated and were followed up to their date of embarkation.

Table 4 shows observed and expected mortality by place of employment for broad diagnostic categories. Deaths from all causes combined were less than expected both in the chemical workers and the hospital employees. The deficit of deaths occurred mainly in the first $\mathbf{1 0}$ years after entry to the cohort, a pattern that would be consistent with a healthy worker effect. The lower than expected level of mortality extended to all the major disease categories except cancer, for which there was a small excess of deaths in both the company and hospital employees.

There were three deaths from leukaemia (two acute myeloid and one lymphatic not further specified) compared with 2.09 expected. Table 5 gives further details. All three deaths occurred in chemical workers with definite exposure to ethylene oxide and after a latency of at least 20 years from first exposure. One man had worked in exposed jobs for three months, one for six years, and one for 14 years. They did not all work in the same company and none of their jobs is likely to have entailed contact with benzene. No further cases of leukaemia were registered among living members of the cohort.

Table 6 gives details of mortality from stomach cancer. Overall, five subjects died from stomach tumours compared with 5.95 expected. All five deaths were in workers in the "definite" or "continual" exposure categories but there were no clear trends in 
relation to duration of exposure or time since first exposure.

Table 7 shows the distribution of deaths from other specific cancers. Slight excesses of deaths were found for oesophageal cancer (five observed, $2 \cdot 20$ expected), lung cancer $(29,24.55)$, bladder cancer (four, 2.04), and non-Hodgkin's lymphoma (four, 1.62) but none was statistically significant at the $5 \%$ level. There were also some deficits. When adjustment was made for local variations in mortality ${ }^{9}$ the overall excess of deaths from cancer was reduced from eight to only three. In particular, the expected number of deaths from lung cancer increased to $26 \cdot 29$.

\section{Discussion}

Concerns about the human carcinogenicity of ethylene oxide have focused particularly on the risk of leukaemia. Evidence for a hazard comes mainly from Sweden where an excess of leukaemia has been observed both in workers exposed to ethylene oxide from its use in the sterilisation of hospital equipment ${ }^{4-6}$ and also in two cohorts of ethylene oxide manufacturers. ${ }^{56}$ Altogether in these studies there have been eight cases of leukaemia when only 0.8 would be expected. ${ }^{6}$ An association with leukaemia has also been suggested by an Italian study of licensed ethylene oxide handlers among whom there were two deaths from the disease as compared with 0.9 expected ( $L$ Bisanti et al, sixth international symposium of epidemiology in occupational health, Stockholm, 1988). On the other hand, no cases of leukaemia were recorded in a study of employees at an ethylene oxide manufacturing plant in the United States ${ }^{10}$; and in a cohort study of chemical workers at eight production plants in West Germany the two observed deaths from leukaemia gave a mortality ratio slightly less than one (N Kieselbach et al, Stockholm, 1988).

In our cohort there were three deaths from leukaemia with 2.09 expected ( 2.45 after adjustment for local variations in mortality rates $\left.{ }^{9}\right)$. All three deaths occurred in chemical workers whose job titles indicated definite exposure to ethylene oxide. Although the men concerned would have come into contact with other chemicals in the course of their work, there was no indication from their occupational histories that they were exposed to known leukaemogens such as benzene. The observation is thus compatible with a weak leukaemogenic effect of ethylene oxide. The absence of a clear excess of leukaemia, however, contrasts with the tenfold increase in risk reported from Sweden ${ }^{6}$-a level of risk that is above our overall reported confidence intervals in table 5. One explanation for the discrepancy may be differences in levels of exposure to ethylene oxide. Many of the Swedish workers are thought to have experienced average exposures greater than $10 \mathrm{ppm}, \overline{\bar{\varrho}}$ whereas in our cohort few, if any, subjects would havez been continuously exposed at this level. Lowero exposures may also explain the apparent absence of risk in the American and West German cohorts. No information on exposure levels is available for the Italian study (L Bisanti et al, Stockholm, 1988). 흘 Another possibility is that the excess of leukaemia in $\frac{\bar{c}}{\frac{1}{\sigma}}$ the Swedish studies is due to confounding exposures, $\stackrel{\mathbb{\Omega}}{\varrho}$ although this seems an unlikely explanation for the three cases found at a sterilising plant where methyl ${ }_{\vec{\circ}}^{\infty}$ formate was the only other exposure of note.

The other cancer that has previously been linked $\overrightarrow{\vec{\omega}}$ with ethylene oxide is carcinoma of the stomach. This $\omega$ association, however, has been less consistent. In one ${ }_{\varnothing}$ cohort of Swedish ethylene oxide manufacturers there 3 have been five deaths from stomach tumours with $0.6+\frac{\circ}{\circ}$ expected $^{6}$ but other studies have shown only small $\vec{N}$ increases in risk or none at all. Our findings-five ${ }_{\infty}^{N}$ deaths compared with 5.95 expected (6.68 after adjustment for local variations in mortality rates ${ }^{9}$ ) - give noo support to the hypothesis that ethylene oxide causes stomach cancer. Again the discrepancy may stem from $\vec{\square}$ differences in exposure levels, but the inconsistency of ${ }_{\varnothing}^{\mathbb{}}$ the observation in other studies suggests that con- $\frac{\mathbb{\Phi}}{3}$ founding or chance variation may be a more likely explanation.

Total cancer mortality in our study was only a littde $\vec{\varphi}$ higher than expected. Although small, the excess of $0_{0}^{\circ}$ non-Hodgkin's lymphoma (four deaths observed, 1 expected) is worth noting, since a similar finding häs recently been reported from Italy (L Bisanti et al). An increased incidence of non-Hodgkin's lymphoma has not, however, been a feature of other studies of $\frac{\circ}{\mathbb{Q}}$ ethylene oxide workers.

We found no important increases in mortality from $\overrightarrow{\overrightarrow{0}}$ causes other than cancer and in particular no support 3 for the suggestion that ethylene oxide might cause circulatory disease. ${ }^{5}$ Deaths from both ischaemic heart disease and cerebrovascular disease were fewer than expected.

In this study we have examined a substantial $\frac{0}{3}$ proportion of the British workforce with a history of occupational exposure to ethylene oxide. Levels of exposure, although lower than in the cohorts reported from Sweden, will have been higher than those found 음 in industry today. Our findings do not exclude the $D$ possibility that ethylene oxide is a human carcinogen, particularly at higher exposures, but when viewed in the context of other published epidemiological studies, $\sigma$ they suggest that any risk of cancer from currently $N$ permitted exposures is small. Why such a powerful $\underset{\omega}{N}$ mutagen is not more carcinogenic in man is unclear.

We are grateful for the cooperation of the four companies and eight hospitals which made this study? 
possible, and for the help of their staff in many ways. We acknowledge the roles of the National Health Service Central Register in Southport and the Department of Health and Social Security in Newcastle in enabling us to follow up the workforce. The study was approved by the British Medical Association Ethical Committee. We thank many colleagues for help with the study, in particular Mr M Merwood and Mr P D Winter for most efficiently carrying out the computer analyses required and Mrs B Howells for carefully preparing the manuscript.

\section{References}

1 International Agency for Research on Cancer. Monographs on the evaluation of the carcinogenic risk of chemicals to man. Vol 36. Allyl compounds, aldehydes, epoxides and peroxides. Lyon: IARC, 1985.
2 Lynch DW, Lewis TR, Moorman WJ, et al. Carcinogenic and toxicologic effects of inhaled ethylene oxide and propylene oxide in F344 rats. Toxicol Appl Pharmacol 1984;76:69-84.

3 Anonymous. Ethylene oxide-a human carcinogen? Lancet 1986; ii:201-2.

4 Hogstedt C, Malmqvist N, Wadman B. Leukaemia in workers exposed to ethylene oxide. JAMA 1979;241:1132-3.

5 Hogstedt C, Rohlen O, Berndtsson BS, Axelson O, Ehrenberg L. A cohort study of mortality and cancer incidence in ethylene oxide production workers. Br J Ind Med 1979;36:276-80.

6 Hogstedt C, Aringer L, Gustavsson A. Epidemiologic support for ethylene oxide as a cancer-causing agent. JAMA 1986;255: 1575-8.

7 World Health Organisation. International classification of diseases. 9th rev. Geneva: WHO, 1977.

8 Hill ID. Computing man years at risk. Br J Prev Soc Med 1972; 26:132-4.

9 Gardner MJ, Winter PD, Taylor CP, Acheson ED. Atlas of cancer mortality in England and Wales, 1968-78. Chichester: Wiley, 1983.

10 Morgan RW, Claxton KW, Divine BJ, Kaplan SD, Harris VB. Mortality among ethylene oxide workers. J Occup Med 1981; 23:767-70.

\section{Destruction of manuscripts}

From 1 July 1985 articles submitted for publication will not be returned. Authors whose papers are rejected will be advised of the decision and the manuscripts will be kept under security for three months to deal with any inquiries and then destroyed. 